\title{
KRISTINA SALONEN
}

\section{MIELENTERVEYS}

\section{AIKUISKASVATUKSEN TAVOITTEENA}

Mielenterveys on käsitteenä ongelmallinen. Parhaimmillaankin se mielletään yleensä vain sairauden vastakohdaksi. Useimmiten se kuitenkin mainitaan puhuttaessa terveyden puutteesta: oireista, häiriöistä, ongelmista. Tästä lähtökohdasta mielenterveyden edistäminen terveyskasvatuksen keinoin olisi lähinnä ongelmien ehkäisemistä, ei pyrkimystä psyykkisen hyvinvoinnin eikä ihmisten toimintamahdollisuuksien lisäämiseen.

Olemme tottuneet ajattelemaan, että terveys on olemassa vain silloin, kun sairaus ei ole läsnä. Emme vielä osaa hahmottaa ihmistä kokonaisuutena, jossa kaikki vaikuttaa kaikkeen. Myös mielenterveys todentuu mielle vasta sairauden tai kriisin kautta; näissä tilanteissa ihminen määrittele, mitä on menettämässä ja mitä se hänelle merkitsee.

Mielenterveyttä voisi voimavarana rinnastaa luonnonvaroihin. Sekin ehtyy, ellei sen hyväksi tehdä työtä. Myös psyykkisen hyvinvoinnin eteen pitäisi nähdä vaivaa aivan samoin kuin huolehdimme fyysisestä kunnostamme; usein ne kulkevatkin käsi kädessä. Mutta psyykkistä hyvinvointiamme säätelevät yhteiskunnalliset reunaehdot vielä enemmän kuin fyysistä, koska yksilön mielenterveys on sidoksissa yhteisön terveyteen. Mielenterveystyö on myös yhteiskunnallista vaikuttamista. Rakentamalla inhimillisesti kestävää ympäristöä voidaan lisätä myös yksilön keinoja selviytyä vaikeissa tilanteissa.

Ihmistä tukevan hyvän elämän perusedellytyksiä voi etsiä arjesta. Niitä ovat perusturvallisuus, mielekäs tekeminen ja sen vastakohtana vapaa- ajan mahdollisuus, riittävä itsetunto, kyky ja halu oppia, mahdollisuus kasvaa ja kehittyä. Tarvitsemme myös toista ihmistä, ystävää, työtoveria, hyväksytyksi tulemisen kokemusta, yhteenkuuluvuutta, palautetta itsestämme.

\section{Mitä tarkoitamme mielenterveydellä?}

Mielenterveyttä on yritetty määritellä monin tavoin. Määritelmät ovat tietysti aina sidoksissa arvoihin ja ihmiskäsitykseen, kysymys on siitä, kenen näkökulmasta joku voi hyvin tai huonosti.

Mielenterveyttä voidaan kuvata esimerkiksi riittäväksi ja olosuhteisiin nähden tyydyttäväksi psyykkiseksi hyvinvoinniksi. Mieleltään terve ihminen pystyy tavallisesti tekemään työtä, ilmaisemaan tunteitaan ja solmimaan ihmissuhteita. Hän osaa asettaa tavoitteensa voimiensa ja mahdollisuuksiensa mukaisiksi, ja hänellä on näkemys vallitsevasta todellisuudesta, jotta hän voi ymmärtää itseään ja ympäristöään. Mutta jos jotkut näistä ehdoista eivät toteudu, se ei tarkoita, ettei ihminen olisi terve tai onnistunut.

Psyykkinen tilamme vaihtelee ajoittain huomattavastikin, eivätkä tilapäiset häiriöt merkitse aina avun tarvetta. Yksikään ihminen ei ole täysin tasapainoinen elämänsä joka hetkenä. Terveen ja sairaan välillä ei aina edes ole selkeää rajaa.

Mielenterveyden ongelmat ovat kuitenkin vakavimpia suomalaisten täyden osallistumisen ja tasa-arvon esteitä. $\mathrm{Ne}$ aiheuttavat monenlaista 
psyykkistä vajaakuntoisuutta ja rajoittavat toiminta- ja työkykyä sekä selviytymismahdollisuuksia. Vakavimmillaan ne vammauttavat toimintakyvyn lähes täysin ja sulkevat yhteiskunnan toimintojen ja sosiaalisten suhteiden ulkopuolelle. Siksi ongelmia on todella syytä yrittää ehkäistä.

Ajoittaiset psyykkiset vaikeudet ja elämänkriisit kuuluvat elämänkulkuun. Hoidettuina ja läpikäytyinä ne vievät elämää eteenpäin ja auttavat kohtaamaan uusia haasteita. Jokainen suhtautuu kokemuksiinsa yksilöllisesti oman elämänhistoriansa, persoonallisuutensa ja ihmissuhteittensa mukaan. Mikään kokemus, ongelma tai kriisi ei ole sellaisenaan pieni tai suuri. Mutta jonkin asian kehittyminen ongelmaksi kertoo, että sen hetkinen elämäntilanne on ylittämäisillään voimat, joten viimeistään silloin siihen pitäisi puuttua.

\section{Voiko mielenterveyttä kasvattaa}

Mielenterveyden yhteydessä puhuisin kasvatuksen sijasta hyvinvoinnin edistämisestä ja tukemisesta. Koko toiminnan pitäisi toteutua ihmisestä itsestään käsin, herättää hänessä oivalluksen kautta halua muutokseen. Se edellyttää tietysti kykyä ja valmiutta nähdä oma elämäntilanne realistisesti ja toimia sen eteen.

Mielenterveystyössä eettinen puoli on ehkä vielä korostuneempi kuin terveyskasvatuksessa yleensä. Mielenterveyden tukeminen ei voi olla ulkokohtaista puuttumista toisen elämään. Kukaan ei voi sanoa, kenen elämä on hyvä ja kenen huono.

Mielenterveydestä ei voi puhua tarttumatta asenteisiin, koska mielen horjumiseen liittyy edelleen ennakkoluuloja, epätietoisuutta, kaavamaista ajattelua: hulluuden stigmasta on jo monen muun sairauden kohdalla päästy.

Mielisairauksiin liittyviä asenteita ja vuorovaikutusta tutkinut Hannu Räty on todennut, että mielenterveyteen liittyy paradoksi: toisaalta mielenterveyden vaihtelut kuuluvat normaaliin elämiseen ja käyttäytymiseen, mutta yhteiskunnan ilmapiiri on sellainen, että niiden esille nostaminen ja niistä puhuminen johtavat yksilötasolla poikkeavuuden leimaan.
Vaikka erilaisuuden hyväksymistä voisi pitää henkisen tason mittana, olemme taipuvaisia pitämään vajaana sitä, joka ei ole enemmistön kaltainen. Siksi myös normaalisuuden käsitettä pitää avartaa. Normaalin käytöksen määrittelemiseen vaikuttavat yksilölliset arviointiperusteemme ja sosiaalisessa ympäristössä vallitsevat käsitykset.

Mielenterveyden edistämiseksi tehtävä työ kohdistuu kaikkiin ihmisiin, ei vain niihin, joilla on ongelmia. Koska psyykkiseen hyvinvointiimme ja vaikeuksista selviytymiseen vaikuttaa suuresti myös se henkinen ilmapiiri, jossa elämme, riskiryhmien sijaan olisi puhuttava riskioloista ja tehtävä työtä niiden korjaamiseksi. Nykyinen terveyskasvatus on mielestäni liian yksilökeskeistä, sillä varsin usein ongelmien takana ovat erilaiset yhteiskunnan rakenteet. Sen enempää fyysisten kuin psyykkisten ongelmien kanssa sinnittelevää ihmistä ei pitäisi koskaan syyllistää, sen sijaan painottaisin yhteisön vastuuta.

Terveyden ylläpitäminen ja edistäminen on ihmisen kannalta elämän mittainen prosessi. Sen jaksamiseen tarvitaan myönteisiä vaihtoehtoja, ei vain kieltoja ja rajoituksia.

Kategorisen ja yhtäältä tulevan terveyskasvatuksen normistot eivät sovellu kaikille, vaan tuntuvat monen ihmisen elämäntilanteen kannalta hyvin ulkokohtaisilta. Terveyskasvattajat ovat oppineet paljon tiedon perillemenosta, eivät vielä niinkään siitä, mikä kaikki on sitä vastaan. Mikä merkitys esimerkiksi terveyttä vaarantavalla tupakoinnilla voi tietyssä elämäntilanteessa olla psyykkiselle selviytymiselle. Tai miten kokemuksen kautta tulleet asiat ovat vahvistaneet asennoitumista terveyteen tai haluun ylläpitää sitä. Terveys kun ei kuitenkaan ole elämän tarkoitus, vaan väline elämän laadun kohottamiseen.

\section{Suomalainen selviää}

Suomen Mielenterveysseura toteuttaa useampivuotista Suomalainen Selviytyjä-hanketta, jolla halutaan korostaan ihmisten omia voimavaroja ja yksilöllisiä selviytymiskeinoja. Tähän teemaan päädyttiin, koska monien elämäntapatutkimusten mukaan suomalainen kokee itsensä selviytyjäksi niin historiallisessa, yhteiskunnallisessa kuin yksilöllisessä viitekehyksessä. Tämä elämänmalli 
sisältää sekä heikkouksiamme että vahvuuksiamme.

Hankkeessa painotetaan selviytymiskeinojen monimuotoisuutta. Jokaisella ihmisellä on luontaiset selviytymiskeinonsa, jotka muotoutuvat oman osaamisen, elämänkokemuksen ja lapsuudessa saatujen mallien mukaan. Näitä keinoja emme kuitenkaan osaa arvostaa riittävästi, vaan olemme antaneet asiantuntijoille liiaksi valtaa sanoa, mitä tarvitsemme ja mikä on meille hyväksi.

Pyrkimyksenä on murtaa myös totunnaisia normaaliuteen liitettyjä käsityksiä, joiden mukana elämä pitäisi elää tietyn mallin mukaan. Olemme normittaneet myös selviytymisen niin tiukasti, että hyväksymämme keinot ovat alkaneet hallita ja kapeuttaa elämää. Pidämme lisäksi epäonnistuneina niitä, jotka eivät selviydy elämässä meidän normiemme mukaan.

Keväällä 1991 toteutettiin hankkeen ensimmäinen viikon mittainen tiedotuskampanja, joka tavoitti ihmisiä yli 8000 toimipisteen kautta. Osa aineistosta suunnattiin suoraan väestölle antamaan tietoa selviytymisestä ja tukemaan omia voimavaroja. Osa palveli auttamistyössä toimivia ammatti-ihmisiä, toimi tukiaineistona heidän jokapäiväisessä työssään ja auttoi myös heitä jatkamaan paremmin ammatissaan.

Kampanjan saamaan hyvään vastaanottoon vaikutti lähestymistapa. Ihmisiä lähestyttiin nostamalla heidät oman elämänsä sankareiksi, hyväksymällä ja arvostamalla heitä omana itsenään. Sitä vastoin esille ei otettu erilaisia elämänrooleja, joiden mukaan ihmisen arvo usein mitataan. Kampanja ei syyllistänyt, kieltänyt eikä paheksunut vaan rohkaisi ihmistä elämään omaa elämäänsä, ottamaan käyttöönsä omat voimavaransa ja luottamaan niihin.

Samalla kuitenkin painotettiin, ettei kenenkään tarvitse selviytyä vaikeuksista yksin. Ihmissuhteiden ja varhaisen avunsaannin merkitys korostuu kriisitilanteissa.

Kampanjassa otettiin huomioon myös se, ettei ihmistä lähestyttäessä riitä pelkkä tieto. Se ei saa aikaan muutoksia, ellei se kulje ensin tunnetason kautta. Tunnetason ottaminen tietotason rinnalle aikaansai sen, että joukkokampanjalla pystyttiin lähestymään ihmisiä henkilökohtaisesti.

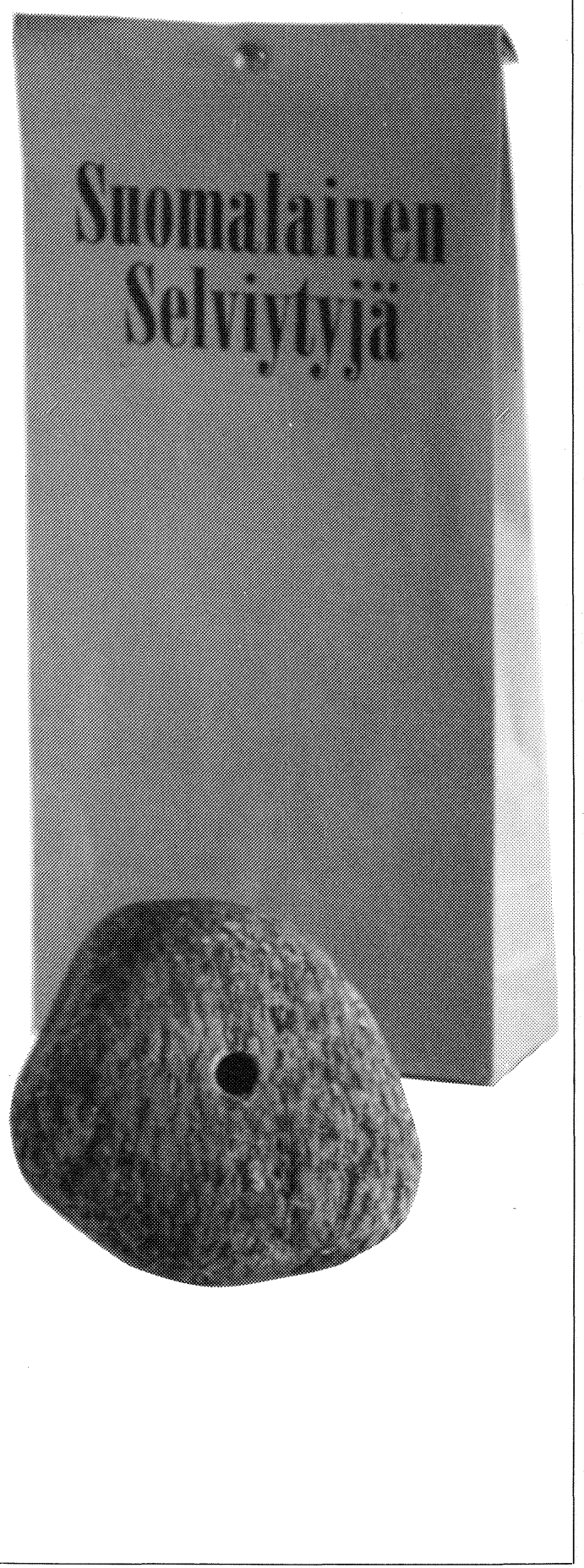

